\section{Thanks to the Clever 'String Pullers' at biotechnet}

\section{Dr. Franz Baumberger, Executive Board biotechnet}

\section{Elsbeth Heinzelmann, Journalist Science and Technology}

Abstract: For years biotechnet Switzerland has provided access to biotechnology capacity at Swiss universities of applied sciences, universities and research centres. Innovative companies put their trust in its support and services in research, development and training. Now two of the individuals who have made biotechnet what it is while keeping it on course for the future are departing.

Keywords: biotechnet · Graf-Hausner, U. · Gygax, D.

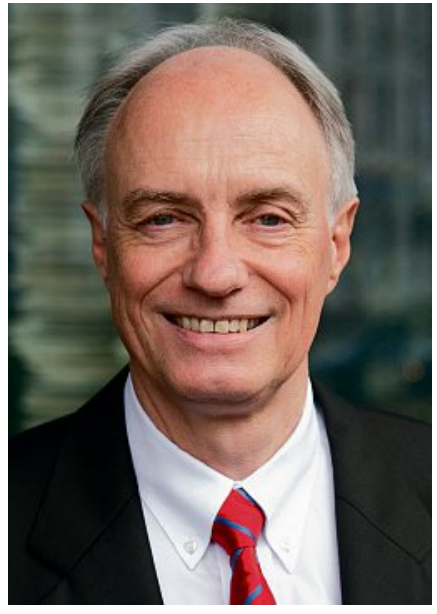

Daniel Gygax, Professor of Bioanalytics and Biotechnology, FHNW School of Life Sciences Basel. Image Jürgen Isler.

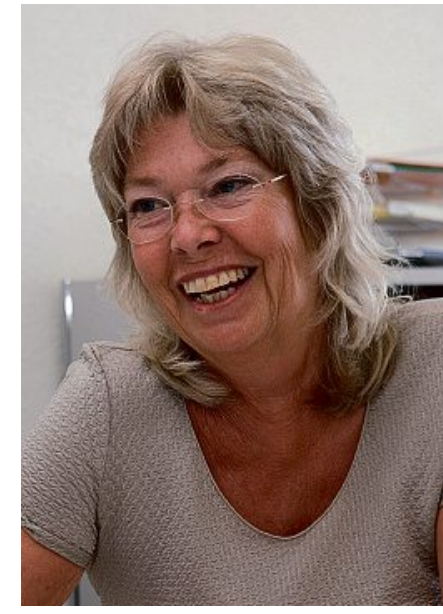

Ursula Graf-Hausner, Professor und Head of Research for Tissue Culture Technology and Tissue Engineering, ZHAW Waedenswil. Image ZHAW Waedenswil.

They were an unbeatable pair of professionals: Daniel Gygax, Professor at the FHNW Muttenz School of Life Sciences, and Ursula Graf-Hausner, Professor and Director of Research in Cell Culture Technology and Tissue Engineering at ZHAW Wädenswil.

\section{The brainy sort}

Daniel Gygax studied biochemistry and microbiology at the Biozentrum of the University of Basel, then worked in enzyme-catalyzed organic synthesis at Harvard University in Cambridge, Massachusetts. After working in immunoanalytics and pharmacokinetics at Novartis, he joined FHNW as a lecturer in 1999, developing teaching and research capacity in biotechnology and bioanalytics. In 2001 he became President of biotechnet.
Ursula Graf-Hausner studied biology and chemistry at the University of Heidelberg and earned her Dr. phil II in biochemistry from the University of Zurich. After working at the former Sandoz AG in Basel, she accepted a position as lecturer at ZHAW Winterthur, then took a sabbatical in cell biology with Novartis Pharma. Back at ZHAW she organized a second sabbatical in Seattle and initiated research projects in dental regeneration using adult stem cells. When Gygax assumed the presidency of biotechnet in 2001, Graf-Hausner became Vice President.

\section{The journey is its own reward}

Both Gygax and Graf-Hausner set biotechnet on a course for success from the very beginning. Thanks to her tight-knit domestic and international research network, the Vice President made extraordinary contributions to achieving the objectives of the CTI, the Commission for Technology and Innovation. She has a good nose for new trends, which she adopts early and implements with determination. As the research networks evolved into national thematic networks, she soon saw the need to forge closer bonds between the business sector and the research institutions. In response she founded TEDD, the Competence Centre for Tissue Engineering for Drug Development and Substance Testing, in Wädenswil. Through tireless efforts, she rapidly persuaded innovative partners from research and industry to become members. Numerous TEDD conferences and symposia fanned the flames of excitement. By now TEDD has roughly 100 members from academia and industry in Switzerland and abroad. Not only her outstanding research track record, but also her open personality, infectious optimism and charm have opened doors for her all over the world and made the TEDD initiative a success story. To ensure that the personal dimension did not lose out, Graf-Hausner initiated an annual two-day retreat where biotechnet members share experiences, set new goals and attend to the social side of their profession over a good meal.

Daniel Gygax maintained close relations with both Professor Oreste Ghisalba, head of CTI Biotech and chairman of the Swiss Biotech Association SBA since 2005, and Dr Hans-Peter Meyer, member of the CTI and the Swiss Academy of Engineering Sciences among others. This helped him form a clear vision of biotechnet which he always defended and determinedly sought to realize. He quickly understood that only a solid alliance with the business sector and the SBA could supply the necessary background to guarantee success. With foresight, he drew the universities of applied science, research institutions and network partners into his plans and won their enthusiastic support.

\section{Actions speak louder than words}

As President of biotechnet he always nurtured a team spirit without losing sight of his goals. At Executive Board meetings he pointed out the extent to which the CTI objectives were being met and where further action was required. Work on the path to the goal went on until all involved were able to follow it. Ten years ago he established a Summer School in cooperation with the University of Palermo. Today the programme is held at a different location 
each year, and its presentations on current issues in biotech attract attendees from all over Europe. The Olten Meeting, an annual gathering of the Swiss biotechnology community with lectures from leading researchers at the international level, was his idea as well.

Gygax always seeks to curb competitive attitudes between the universities of applied sciences in favour of an open exchange of ideas. In keeping with the CTI philosophy, he supports a strategy in which every institution seeks not to cover the entire spectrum, but to focus on its own specialisms. Because international relations are of particular interest to him, he spends time at Harvard University in Cambridge, Massachusetts every year to exchange views with colleagues at the George Whitesides Research Group and discuss the latest trends and developments.

Now that both scientists are leaving the biotechnet stage, their departure clears a space for new ideas and inspirations to be translated into action. Ursula Graf-Hausner has also established a firm, www.3dcellculture.ch, to share her knowledge and wealth of experience by offering scientific expertise, coaching and consulting to successfully position businesses in the 3D cell culture market.

Gygax plans to chair the Scientific Advisory Board of the new National Thematic Network (NTN) affiliated to biotechnet, assuming responsibility for the fulfilment of CTI requirements.

Not only their fellow members of the biotechnet Executive Board, but all researchers, scientists and industry representatives on the Swiss biotech scene wish to express their sincere gratitude to these two creative individuals. We wish them much happiness in their future personal lives and all manner of success in their further professional activities.

Biotechnet and Swiss Biotech Association (SBA) are founders and members of the CTI National Thematic Network.

Received: July 29, 2016 